\title{
Optimizing the use of potassium sorbate and sodium metabisulphite for the chemical and microbial stability of carbonated coconut water
}

\author{
Otimizando o uso de sorbato de potássio e metabissufito de sódio para a \\ estabilidade química e microbiológica de água de coco carbonatada
}

\section{Autores | Authors}

Eliene Penha Rodrigues

PEREIRA

Universidade Estadual de Campinas (UNICAMP)

Departamento de Tecnologia de Alimentos Campinas/SP - Brasil e-mail: eliene.prp@uol.com.br

$\square$ José de Assis Fonseca FARIA

Universidade Estadual de Campinas (UNICAMP)

Departamento de Tecnologia de Alimentos Rua Monteiro Lobato, 80 CP 6121

CEP: 13083-862

Campinas/SP - Brasil e-mail: assis@fea.unicamp.br

\section{Uelinton Manoel PINTO \\ Universidade Federal de Ouro Preto (UFOP) \\ Departamento de Alimentos Ouro Preto/MG - Brasil e-mail: velintonpinto@gmail.com}

$\square$ Autor Correspondente / Corresponding Author

Recebido / Received: 24/04/2012 Aprovado / Approved: 13/03/2013 Publicado / Published: jun./2013

\section{Summary}

Coconut water is popular worldwide, mainly because of its pleasant sensory characteristics, nutritional value and low calorie density. However, coconut water is a highly perishable product due to the presence of enzymes such as peroxidase and polyphenoloxidase, which cause undesirable changes in colour, and also because of its susceptibility to microbial spoilage. The use of chemical additives has been adopted by the industry with the intent of increasing product shelf life. In this study, the efficiency of the preservatives potassium sorbate and sodium metabisulphite was assessed using a Central Composite Rotational Design (CCRD) to determine the stability of carbonated coconut water, varying the concentrations of potassium sorbate from 0 to $500 \mathrm{mg} \cdot \mathrm{L}^{-1}$, and of sodium metabisulphite from 0 to $100 \mathrm{mg}^{\mathrm{L}} \mathrm{L}^{-1}$. The chemical evaluations included carbonation volume, $\mathrm{pH}$, soluble solids, dissolved oxygen and carbon dioxide, acidity, ascorbic acid, polyphenoloxidase and peroxidase activities, colour and turbidity attributes. The microbiological evaluations considered the total aerobic plate count and the enumeration of yeasts and moulds. It was observed that concentrations of $375 \mathrm{mg} . \mathrm{L}^{-1}$ of potassium sorbate and $75 \mathrm{mg} . \mathrm{L}^{-1}$ of sodium metabisulphite gave the best quality attributes with respect to minor changes in acidity and colour of the coconut water, providing that the raw material had low microbiological contamination.

Key words: Coconut water; Carbonation; Potassium sorbate; Sodium metabisulphite; Microbiological quality.

\section{Resumo}

A água de coco é muito popular em todo o mundo, principalmente em virtude das suas características sensoriais agradáveis, do valor nutricional e das baixas calorias. No entanto, a água de coco é um produto altamente perecível em função da presença de enzimas - tais como peroxidase e polifenoloxidase, que causam alterações indesejáveis na cor - e também em função da sua susceptibilidade à deterioração microbiana. $\mathrm{O}$ uso de aditivos químicos tem sido adotado pela indústria com a intenção de aumentar a vida de prateleira do produto. Neste estudo, a eficiência dos conservantes sorbato de potássio e metabissulfito de sódio foi avaliada considerando-se a estabilidade da água de coco carbonatada por meio do delineamento composto central rotacional (DCCR), variando as concentrações de sorbato de potássio entre 0 e $500 \mathrm{mg} \cdot \mathrm{L}^{-1}$, e de metabissulfito de sódio entre 0 e $100 \mathrm{mg} \cdot \mathrm{L}^{-1}$. Foram realizadas avaliações físico-químicas de volume de carbonatação, $\mathrm{pH}$, sólidos solúveis totais, oxigênio e dióxido de carbono dissolvidos, acidez, ácido ascórbico, atividade de polifenoloxidase e peroxidase, cor e atributos de turbidez. As análises microbiológicas realizadas foram de contagem total de aeróbios, bem como de enumeração de bolores e leveduras. Observou-se que as concentrações de $375 \mathrm{mg} \cdot \mathrm{L}^{-1}$ de sorbato de potássio e $75 \mathrm{mg} \cdot \mathrm{L}^{-1}$ de metabissulfito de sódio apresentaram os melhores atributos de qualidade, no que diz respeito a pequenas alterações na acidez e à cor da água de coco, desde que a matéria-prima apresentasse contaminação microbiológica baixa.

Palavras-chave: Água de coco; Carbonatação; Sorbato de potássio; Metabissulfito de sódio; Qualidade microbiológica. 


\section{Introduction}

Coconut water is a beverage appreciated worldwide. It is a drink with a slight sweet and acid flavour ( $\mathrm{pH}$ 5.5), it is somewhat cloudy and it is constituted mainly of minerals and sugars, and in smaller proportions, by nitrogenous substances (amino-acids), lipids and vitamins. Due to its rich composition in salts, it is considered as a natural isotonic drink (MEDINA et al., 1980; MACIEL et al., 1992; CAMPOS et al., 1996).

Coconut water is a highly nutritious beverage which favours microbial spoilage. The product is also susceptible to browning due to high oxido-reductase enzyme concentrations such as polyphenoloxidase and peroxidase.

Polyphenoloxidase catalyzes two types of oxidative reactions: hydroxylation of monophenols into o-diphenols and the oxidation of the latter compounds, which are colourless, into dark toned o-quinones (DUARTE et al., 2002).

Peroxidase, on the other hand, catalyzes a great number of oxidative reactions using hydrogen peroxide as the substrate, or, in some cases, oxygen as a hydrogen acceptor. Peroxidase is considered to be the most heat stable vegetable enzyme and its inactivation has conventionally been used as an indicator of blanching efficacy in vegetable processing (FREITAS et al., 2008).

Enzymatic browning is usually undesirable and therefore chemical and physical methods have been developed aiming at its inhibition, which can be achieved by the elimination or complexation of one or more essential components of the reaction such as oxygen, enzyme, copper or substrate (GUERRERO-BELTRÁN et al., 2005).

The only normative instruction in Brazil concerning processed coconut water applies to its physicochemical characteristics (BRASIL, 2009), and there is no specific legislation concerning the use of preservatives for this product. Thus different compounds are used according to the specific legislation for fruit juices, that is, $0.004 \mathrm{~g} .100 \mathrm{~mL}^{-1}$ of sodium sulphite and $0.03 \mathrm{~g} .100 \mathrm{~mL}^{-1}$ of sorbic acid in the carbonated beverages (BRASIL, 2007). Ascorbic acid is frequently used to prevent enzymatic browning, and has been shown to be more effective than its isomer, iso-ascorbic acid. This acid acts as an antioxidant, reducing the quinine produced by polyphenoloxidase, and contributing to a drop in the $\mathrm{pH}$ value. However, ascorbic acid can also participate in the non-enzymatic browning process by forming furfural derivatives in the presence of low $\mathrm{pH}$ and heating, producing dark pigments (QUEIROZ et al., 2008; TORALLES et al., 2008).

In a study by Abreu and Faria (2007), ascorbic acid

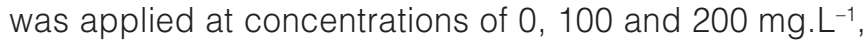
together with heat treatments varying between 138 and $144^{\circ} \mathrm{C}$ for 10 seconds. They found that a heat treatment of $139^{\circ} \mathrm{C}$ for 10 seconds plus the addition of $200 \mathrm{mg} . \mathrm{L}^{-1}$ of ascorbic acid provided the best physicochemical stability for aseptically packed coconut water.

Sulphites are widely used to prevent browning, either by enzymatic or non-enzymatic means. They are also used in the control of microorganisms as antioxidants or reducing agents, amongst other functions. However, due to its adverse health effects, the World Health Organization (WHO) limits the use of sulphur dioxide $\left(\mathrm{SO}_{2}\right)$ in processed food products to a maximum daily dose of $0.7 \mathrm{mg} \mathrm{kg}^{-1}$ of body mass (QUEIROZ et al., 2008; FAO, 1967).

Although sulphur dioxide and sulphites are generally recognized as safe (GRAS) substances, their use in wines is limited to $0.035 \%$ because higher levels could lead to undesirable flavours. The use of sulphites is not allowed in foods that are considered as sources of thiamine since they inactivate this vitamin (MAGA and TU, 1994; MITCHELL, 1990).

According to Maga and Tu (1994), the intake of sulphite at normal levels in foods does not result in accumulation in the body, because it is rapidly oxidized into sulphate and excreted in the urine. However, a dose above tolerable levels (such as $62 \mathrm{mg} \cdot \mathrm{kg}^{-1}$ of body mass) of sulphur dioxide has resulted in neurological problems in rats, including polyneuritis, visceral atrophy, bone marrow atrophy, renal dysfunction and growth limitation. In direct contact with the eyes, $\mathrm{SO}_{2}$ is quickly absorbed and gets into the cornea, causing acute inflammation. However, in general, no mutagenic, teratogenic or carcinogenic effects of $\mathrm{SO}_{2}$ have been observed in rats or mice (MAGA and TU, 1994; MITCHELL, 1990). However, sulphites have been associated with asthmatic attacks and other allergenic effects, and in extreme cases they are able to cause death due to hypersensitivity.

Sorbic acid and sorbates are generally used in the control of microorganisms in industrialized food products, with a maximum recommended daily intake of $12.5 \mathrm{mg} \cdot \mathrm{kg}^{-1}$ of body mass (MITCHELL, 1990; FAO, 1967). For the microbiological preservation of coconut water, many authors have used pre-determined concentrations of preservatives such as: $40 \mathrm{mg} \cdot \mathrm{L}^{-1}$ of sodium metabisulphite

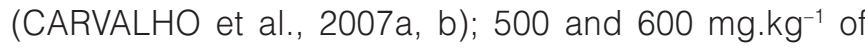
potassium metabisulphite (CHOWDHURY et al., 2005); $45 \mathrm{mg} . \mathrm{L}^{-1}$ of sodium metabisulphite and $124 \mathrm{mg} \cdot \mathrm{L}^{-1}$ of sodium benzoate (SILVA et al., 2003), despite the fact that no study has been carried out to determine the minimum concentration necessary to preserve coconut water.

The present research analyzed the combined action of potassium sorbate at concentrations ranging from 0 to $500 \mathrm{mg} . \mathrm{L}^{-1}$ with sodium metabisulphite at concentrations from 0 to $100 \mathrm{mg} \cdot \mathrm{L}^{-1}$. These concentrations were chosen in order to obtain samples containing only one of the preservatives and also concentrations above those 
permitted by the Brazilian law. The effect of carbonation was also assessed, since it is generally known to provide a refreshing sensation and also because of a possible role in microbial growth inhibition.

\section{Experimental procedures}

\subsection{Materials}

Green coconuts of the dwarf variety were used with maturity levels of approximately 6 to 7 months, bought from the Central Supply Unit in Campinas - SP (CEASA), Brazil. For standardization of the coconut water (Brix $=7^{\circ} \mathrm{Brix}$ and $\mathrm{pH}$ between 4.3-4.5), refined sugar was used as a source of sucrose (Caravelas brand, Usina Colombo, Ariranha - SP, Brazil), and citric acid (Synth brand, Labsynth, Diadema - SP, Brazil). Ascorbic acid (Nuclear brand, Casa da Química, Diadema - SP, Brazil) was used at a concentration of $200 \mathrm{mg} \cdot \mathrm{L}^{-1}$, and the chemical preservatives potassium sorbate (Vetec brand, Vetec,

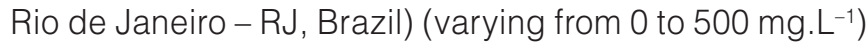
and sodium metabisulphite (Synth brand, Labsynth, Diadema - SP, Brazil), (varying from 0 to $100 \mathrm{mg}^{\mathrm{L}} \mathrm{L}^{-1}$ ) were also employed.

As for the packaging system, transparent polyethylene terephthalate (PET) bottles were used, provided by Minalba (Minalba, São José dos Campos - SP). The characteristics of the bottles were: weight of $16.49 \pm 0.05 \mathrm{~g}$, volumetric capacity of $348.58 \pm 1.32 \mathrm{~mL}$ and oxygen permeability of $0.047 \pm 0.001 \mathrm{~cm}^{3} /$ bottle. day.atm at $25^{\circ} \mathrm{C}$. High density polyethylene screw caps containing Bericap seal liners (Sorocaba-SP) were used to close the bottles,.

\section{Methods}

Before extracting the water from the fruits, they were sanitized using a solution of sodium hypochlorite (200 mg. $\mathrm{L}^{-1}$ ). The water was then standardized to a $\mathrm{pH}$ between 4.3-4.5 and $7^{\circ}$ Brix using citric acid and sucrose. At this point, $200 \mathrm{mg} . \mathrm{L}^{-1}$ of ascorbic acid were added to the water. The drink was clarified by passing through a $1 \mu \mathrm{m}$ pore opening filter, pasteurized at $90{ }^{\circ} \mathrm{C}$ for 30 seconds, and rapidly cooled to $2^{\circ} \mathrm{C}$ in a plate heat exchanger (model Micro Plak Jr., manufactured by Suma Brand Indústria e Comércio Ltda., Campinas - SP, Brazil),

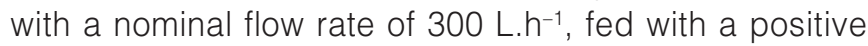
displacement pump (Netzsch brand, Pomerode - SC, Brazil). The coconut water was carbonated to 2 to 3 volumes in a carbonating machine developed by Faria
(2007). This step consisted of injecting carbon dioxide into the beverage under pressure to obtain the desired degree of carbonation. The drink was packaged into PET bottles, previously cleaned with a sodium hypochlorite solution (200 mg. $\left.\mathrm{L}^{-1}\right)$ and stored at room temperature $\left(20 \pm 1^{\circ} \mathrm{C}\right)$ for 62 days. The preservatives were added before carbonation. The concentration used was established by a Central Composite Rotational Design (CCRD) with two independent variables (potassium sorbate and sodium metabisulphite) at concentrations varying from 0 to $500 \mathrm{mg} \cdot \mathrm{L}^{-1}$ and 0 to $100 \mathrm{mg} \cdot \mathrm{L}^{-1}$, respectively, as shown in Table 1. The responses obtained were statistically analyzed using the STATISTICA 7 program.

\subsection{Evaluation of stability}

To evaluate the stability, the carbonation volume was analysed according to the ASTM F1115-95 standards (ASTM, 2001); the $\mathrm{pH}$ was determined using a Digimed potentiometer (Sao Paulo - SP, Brazil), model DM-20 at $25{ }^{\circ} \mathrm{C}$; the soluble solids were determined using a portable refractometer (Optech, model RCZ, Guarulhos - SP, Brazil); dissolved $\mathrm{O}_{2}$ was assessed using an $\mathrm{O}_{2}$ meter (Mettler Toledo, model MO128, Barueri - SP, Brazil); dissolved $\mathrm{CO}_{2}$ was evaluated using a $\mathrm{CO}_{2}$ electrode (Thermo Scientific, model Orion 720A - represented in Brazil by Analyser, Sao Paulo - SP); colour and turbidity were determined in a colorimeter (Hunterlab, model Colorquest II, using the CIELAB system with the illuminant D65, observer's angle of $10^{\circ}$, TTRAN-type calibration and HAZE measurement - turbidity).

Titratable acidity was determined based on method 942.15 of AOAC (HORWITZ, 1997). The ascorbic acid concentration was determined by titrating $10 \mathrm{~mL}$ of sample with $50 \mathrm{~mL}$ of a $1 \%$ oxalic acid solution standardized with a solution of $2 \mathrm{~g} . \mathrm{L}^{-1}$ dichloroindophenol (DCFI). A spectrophotometer (Beckman, model DU-70) was used to determine the peroxidase and polyphenoloxidase activities. For polyphenoloxidase, $1.3 \mathrm{~mL}$ of $0.35 \mathrm{M}$ phosphate buffer ( $\mathrm{pH} 6.0$ ), $0.7 \mathrm{~mL}$ of $0.2 \mathrm{M}$ catechol and $2 \mathrm{~mL}$ of the coconut water sample were mixed at room temperature, and the absorbance read at $425 \mathrm{~nm}$ in a spectrophotometer at zero time and after 10 minutes of reaction. For peroxidase, $1.3 \mathrm{~mL}$ of $0.35 \mathrm{M}$ phosphate buffer ( $\mathrm{pH} \mathrm{5.5)}$ at $35{ }^{\circ} \mathrm{C}$ was used, and $2 \mathrm{~mL}$ of the coconut water sample added together with $0.5 \mathrm{~mL}$ of an alcoholic solution of $0.5 \%$ guaiacol and $0.2 \mathrm{~mL}$ of $0.1 \%$ hydrogen peroxide. The absorbance was read at $470 \mathrm{~nm}$

Table 1. Design Matrix for $2^{2}$.

\begin{tabular}{lccccccccccc}
\multicolumn{1}{c}{ Assay } & A & B & C & D & E & F & G & H & I & J & K \\
Potassium Sorbate $\left(\mathrm{mg} \cdot \mathrm{L}^{-1}\right)$ & 73 & 427 & 73 & 427 & 0 & 500 & 250 & 250 & 250 & 250 & 250 \\
Sodium Metabisulphite $\left(\mathrm{mg}^{\mathrm{L}} \mathrm{L}^{-1}\right)$ & 15 & 15 & 85 & 85 & 50 & 50 & 0 & 100 & 50 & 50 & 50 \\
\hline
\end{tabular}


Optimizing the use of potassium sorbate and sodium metabisulphite for the chemical and microbial stability of carbonated coconut water

PEREIRA, E. P. R. et al.

in a spectrophotometer at zero time and after 10 minutes of reaction.

For the microbiological evaluations, the total aerobic plate count was obtained by pour plating $1 \mathrm{~mL}$ of each dilution into Plate Count Agar (PCA). The colonies were counted after 48 hours of incubation at $35^{\circ} \mathrm{C}$ and expressed as Colony Forming Units per $\mathrm{mL}\left(\mathrm{CFU} \cdot \mathrm{mL}^{-1}\right)$. The yeast and mould count was obtained by surface plating $1 \mathrm{~mL}$ of each dilution in Potato Dextrose Agar (PDA) and counting after 5 days at $23^{\circ} \mathrm{C}$ (SILVA et al., 2010). The microbiological evaluation was carried out at zero time and after 30 and 61 days of storage.

\section{Results and discussion}

The samples were evaluated during 62 days of storage at room temperature $\left(20 \pm 2{ }^{\circ} \mathrm{C}\right)$. At the end of the storage period, it was shown that the concentration of the preservatives influenced the results with a significance of $10 \%$ for the carbonation volume, $\mathrm{pH}$, dissolved $\mathrm{CO}_{2}$, titratable acidity, ascorbic acid concentration, colour $b^{*}$ and turbidity attributes, as shown in Table 2.

Ignoring the non-significant effects, the following 7 equations were obtained, and it was also possible to calculate the analysis of variance (ANOVA) for each of the attributes, as presented in Table 3.

Carbonation volume $=2.07-0.24 x_{1}-0.18 x_{2}+0.15 x_{2}^{2}$
$\mathrm{pH}=4.05+0.06 \mathrm{x}_{1}+0.03 \mathrm{x}_{2}-0.02 \mathrm{x}_{2}^{2}$

$\mathrm{CO}_{2}\left(\mathrm{mg} \cdot \mathrm{L}^{-1}\right)=4960.45-158.16 \mathrm{x}_{2}$

Titratable acidity $(\mathrm{mL} \mathrm{NaOH} 0.1 \mathrm{~N} / 100 \mathrm{~mL}$ of sample $)=$ $36.88-3.86 \mathrm{x}_{1}+2.28 \mathrm{x}_{1}^{2}$

Ascorbic acid $\left(\mathrm{mg} \cdot \mathrm{L}^{-1}\right)=173.68+16.82 \mathrm{x}_{1}-19.13 \mathrm{x}_{1}^{2}$

Colour $b^{*}=5.98-1.30 x_{1}+0.99 x_{1}^{2}-3.13 x_{2}$

Turbidity $=43.17-12.20 \mathrm{x}_{2}$

where: $x_{1}$ : Concentration of potassium sorbate and $x_{2}$ : concentration of sodium metabisulphite.

All regressions were significant with a significance level of $10 \%$. It was possible to construct response surfaces for each attribute as presented in Figure 1.

The response surface for carbonation volume (Figure 1a) showed an inverse correlation, with lower concentrations of the two preservatives giving greater carbonation volumes. However, the inverse behaviour was observed for $\mathrm{pH}$ (Figure 1b), with lower concentrations of the two preservatives giving lower $\mathrm{pH}$ values.

Table 2. Estimated effects for a second order fit, representing the relationship between the responses and process variables.

\begin{tabular}{|c|c|c|c|c|c|c|c|c|c|c|c|c|}
\hline & \multicolumn{12}{|c|}{ Estimated effects } \\
\hline & Carbonation & pH & $\mathrm{CO}_{2}$ & SS & Acidity & AA & PER & PFO & $\begin{array}{c}L^{*} \\
\text { Colour }\end{array}$ & $\begin{array}{c}a^{*} \\
\text { Colour }\end{array}$ & $\begin{array}{c}b^{*} \\
\text { Colour }\end{array}$ & Turbidity \\
\hline Average & $2.00^{*}$ & $4.05^{*}$ & $4813.33^{*}$ & $6.80^{\star}$ & $35.87^{\star}$ & $175.75^{\star}$ & 0.0233 & 0.0267 & $93.70^{\star}$ & $-0.47^{*}$ & $4.89^{*}$ & $33.88^{*}$ \\
\hline (1) $\times 1(L)$ & $-0.48^{\star}$ & $0.12^{*}$ & -149.36 & 0.38 & $-7.72^{\star}$ & $33.64^{\star}$ & 0.0775 & 0.1580 & 0.59 & -0.19 & $-2.59^{\star}$ & -12.95 \\
\hline$X 1(Q)$ & 0.15 & -0.01 & 89.79 & 0.22 & $5.18^{*}$ & $-39.54^{*}$ & 0.0154 & 0.1121 & -0.65 & -0.07 & $2.66^{\star}$ & 7.59 \\
\hline (2) $\times 2(L)$ & $-0.37^{\star}$ & $0.05^{\star}$ & $-316.31^{\star}$ & 1.13 & -2.07 & 8.79 & -0.0775 & -0.2469 & 0.40 & 0.16 & $-6.26^{\star}$ & $-24.40^{*}$ \\
\hline ×2 (Q) & $0.35^{\star}$ & $-0.05^{\star}$ & 314.79 & -0.85 & 2.13 & -4.39 & 0.0154 & 0.0946 & 0.34 & 0.21 & 2.31 & 17.97 \\
\hline$(1) \times(2)$ & 0.37 & -0.03 & -327.50 & -0.20 & -1.27 & 17.58 & -0.1550 & -0.2700 & 0.67 & 0.40 & 0.18 & 13.89 \\
\hline
\end{tabular}

${ }^{*}$ Significant estimated effects at $10 \%$. $\mathrm{CO}_{2}$ : concentration of dissolved $\mathrm{CO}_{2}$ in $\mathrm{mg} . \mathrm{L}^{-1}$; SS: soluble solids in ${ }^{\circ}$ Brix; Acidity: measured in mL of $\mathrm{NaOH}$ 0,1N/100mL; AA: concentration of ascorbic acid in mg. L-1; PER: peroxidase activity in U. $\mathrm{mL}^{-1}$; PFO: polyphenoloxidase activity in U.mL $\mathrm{mL}^{-1}$

Table 3. ANOVA

\begin{tabular}{|c|c|c|c|c|c|c|c|c|c|c|c|c|c|c|}
\hline & \multicolumn{2}{|c|}{ Carbonation } & \multicolumn{2}{|r|}{ pH } & \multicolumn{2}{|r|}{$\mathrm{CO}_{2}$} & \multicolumn{2}{|c|}{ Acidity } & \multicolumn{2}{|r|}{ AA } & \multicolumn{2}{|c|}{ b* Colour } & \multicolumn{2}{|c|}{ Turbidity } \\
\hline & LD & SQ & LD & SQ & LD & SQ & LD & SQ & LD & SQ & LD & SQ & LD & SQ \\
\hline Regression & 3 & 0.8692 & 3 & 0.0396 & 1 & 200105.26 & 2 & 151.11 & 2 & 4524.88 & 3 & 97.79 & 1 & 1190.57 \\
\hline Residue & 7 & 0.3565 & 7 & 0.0047 & 9 & 522317.47 & 8 & 36.23 & 8 & 1315.77 & 7 & 18.43 & 9 & 1617.71 \\
\hline Lack of fit & 5 & 0.2356 & 5 & 0.0047 & 7 & 461050.81 & 6 & 33.99 & 6 & 1315.77 & 5 & 17.59 & 7 & 1614.97 \\
\hline Pure Error & 2 & 0.1209 & 2 & 0.0001 & 2 & 61266.67 & 2 & 2.24 & 2 & 0.00 & 2 & 0.84 & 2 & 2.75 \\
\hline Total & 10 & 1.2257 & 10 & 0.0444 & 10 & 722422.73 & 10 & 187.34 & 10 & 5840.65 & 10 & 116.22 & 10 & 2808.28 \\
\hline $\mathrm{R}^{2}$ & & 0.92 & & 9.34 & & 27.7 & & 0.66 & & 77.47 & & 4.14 & & 42.39 \\
\hline
\end{tabular}

LD: liberty degrees; SQ: sum of the squares; $\mathrm{CO}_{2}$ : concentration of $\mathrm{CO}_{2}$ dissolved in $\mathrm{mg}$. $\mathrm{L}^{-1}$; Acidity: measured in $\mathrm{mL}$ of $\mathrm{NaOH} 0,1 \mathrm{~N} / 100 \mathrm{~mL}$; AA: concentration of ascorbic acid in $\mathrm{mg} \cdot \mathrm{L}^{-1}$ 
Optimizing the use of potassium sorbate and sodium metabisulphite for the chemical and microbial stability of carbonated coconut water

PEREIRA, E. P. R. et al.

(a)

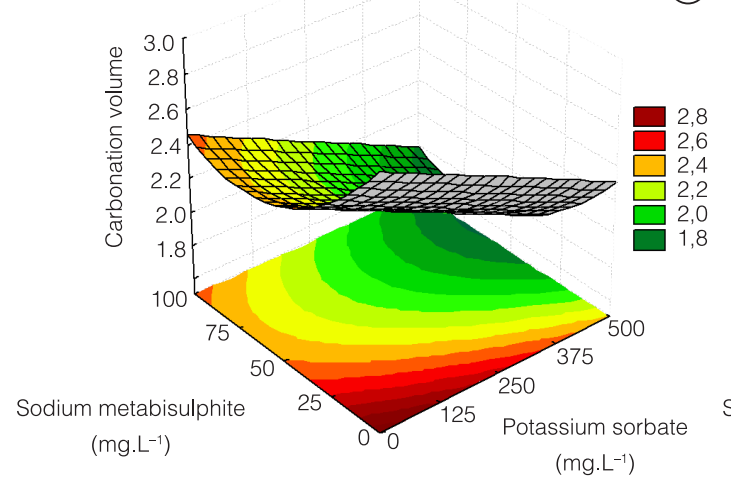

(C)

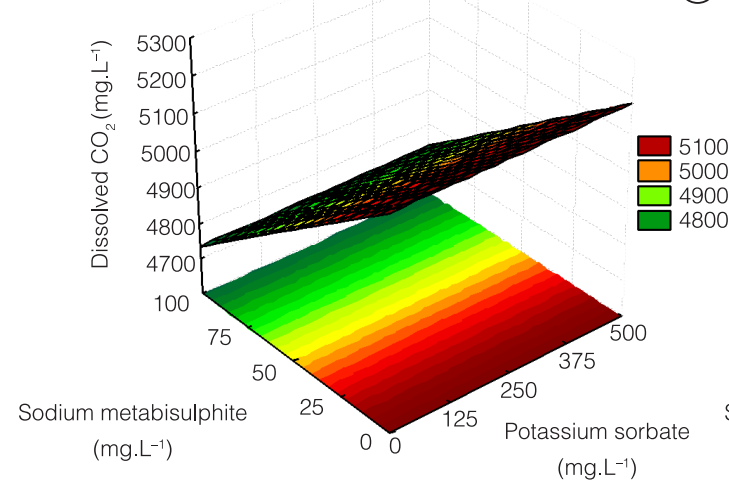

(e)
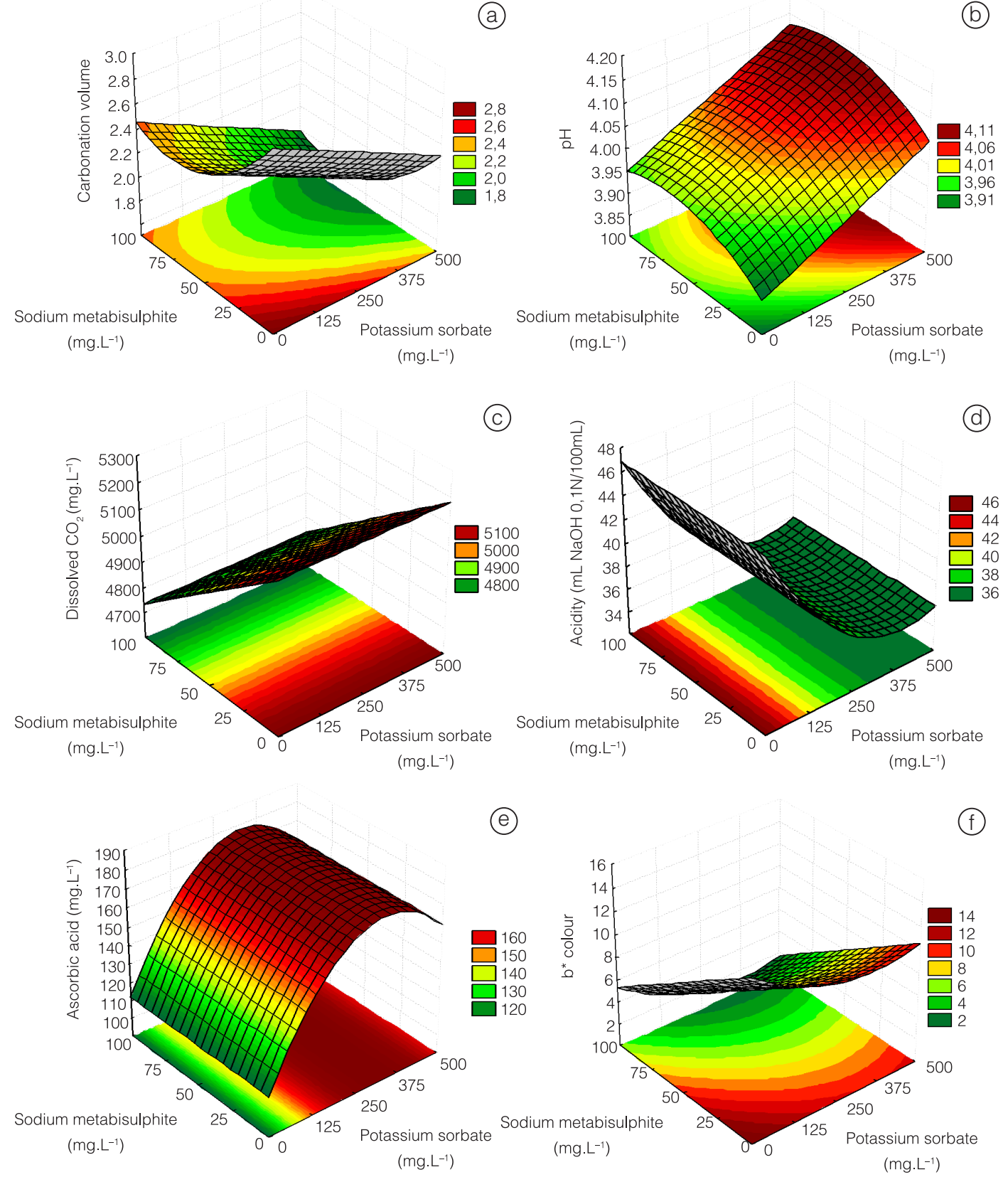

(f)

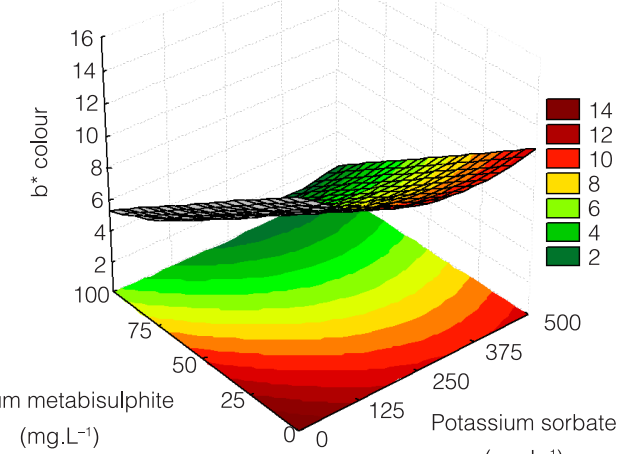

$\left(\mathrm{mg} . \mathrm{L}^{-1}\right)$

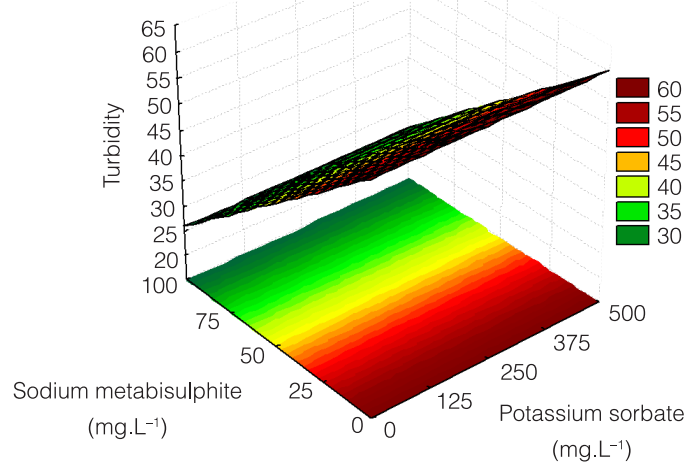

Figure 1. Response surfaces for: (a) carbonation volume, (b) $\mathrm{pH}$, (c) dissolved $\mathrm{CO}_{2}$, (d) titratable acidity (e) ascorbic acid concentration, (f) $b^{*}$ colour and $(g)$ turbidity. 
In the determination of dissolved $\mathrm{CO}_{2}$ (Figure 1c), only sodium metabisulphite showed a significant response, with lower concentrations of this preservative giving rise to greater quantities of dissolved gas. As for acidity (Figure 1d) only potassium sorbate was significant, and the lower its concentration, the higher the acidity developed in the sample.

In the determination of ascorbic acid, only potassium sorbate showed a significant response, and the lower the concentration of potassium sorbate, the greater the degradation of ascorbic acid, as seen in Figure 1e. Lima et al. (2009) also found a decrease in ascorbic acid concentration in coconut water-acerola fruit juice supplemented with caffeine, at a rate of $1.24 \mathrm{mg} .100 \mathrm{~mL}^{-1}$.day ${ }^{-1}$

For the $b^{*}$ colour attribute, low sodium metabisulphite concentrations, and very low or very high potassium sorbate concentrations favoured the development of a yellow colour (higher values for b*) (Figure 1f). However for turbidity, only sodium metabisulphite had a significant effect, with lower concentrations allowing for the development of more turbidity in the samples (Figure 1g). These results could be associated with the growth of microorganisms forming gas and acid, since the sample would be less protected due to the lower concentrations of preservative, as shown in Table 4.

The microbiological evaluations of the samples (formulations presented in Table 1) were carried out at zero time and after 30 and 61 days of storage at room temperature, according to Table 4. Samples A, $B, C, E$ and $G$ presented a total microbial count above $10^{3}$ CFU. $\mathrm{mL}^{-1}$ after 30 days of storage. Samples A, B and $C$ showed decreases in the microbial counts after 61 days, which could be attributed to the start of the decline phase of microbiological development. Samples $E$ and $G$ showed an increase in the microbial count at the end of the observation period. With the exception of sample B, all the samples contained the lowest concentrations of the preservatives, and samples $E$ and $G$ only contained sodium metabisulphite and potassium sorbate, respectively. These results indicated there was a certain synergism between the two preservatives with respect to microbial control. The other samples, D, F, H and $\mathrm{K}$, showed no significant microbial development at any point.

For the yeast and mould counts, samples A, B, C, $E, G$ and I presented detectable counts after 30 days of storage, with $E$ and $G$ having counts above $10^{5} \mathrm{CFU}$. $\mathrm{mL}^{-1}$. After 61 days, there was an increase in the yeast and mould counts for samples $A, E$ and $G$, with $E$ and G showing total counts above $10^{6} \mathrm{CFU} \cdot \mathrm{mL}^{-1}$, a fact that confirms the efficacy of the combined action provided by the two preservatives.

The activities of the enzymes polyphenoloxidase and peroxidase were not significant in any of the samples during the storage time, indicating that the thermal processing applied to the samples was sufficient to inactivate them. As in the study of Murasaki-Aliberti et al. (2004), heat processing with shorter holding times can minimize the nutritional and sensory losses in coconut water and promote $90 \%$ enzymatic inactivation.

Based on the present results, concentrations of 375 and $75 \mathrm{mg} . \mathrm{L}^{-1}$ of potassium sorbate and sodium metabisulphite, respectively, caused less changes in all the attributes evaluated. However, such concentrations are not allowed by the Brazilian legislation (BRASIL,

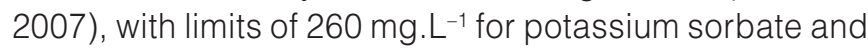
$40 \mathrm{mg} . \mathrm{L}^{-1}$ for sodium metabisulphite. According to the present results, this combination would also be sufficient to preserve the product, and thus additional confirmatory trials were carried out using these concentrations, as well as the optimal combination. However, these confirmatory trials showed very high microbiological contamination, with counts of over $10^{8} \mathrm{CFU} \cdot \mathrm{mL}^{-1}$ over a period of 20 days of storage for both samples, indicating that these concentrations of the preservatives were not sufficient to

Table 4. Total and yeast and mould counts for samples A, B, C, D, E, F, G, H, I, J and K, after 0,30 and 61 days of storage.

\begin{tabular}{|c|c|c|c|c|c|c|c|c|c|c|c|c|}
\hline & Sample & A & B & C & D & $E$ & $\mathbf{F}$ & G & $\mathrm{H}$ & I & $\mathbf{J}$ & K \\
\hline \multirow[t]{2}{*}{0 days } & $\begin{array}{l}\text { Total Count } \\
\left.\text { (CFU.mL }{ }^{-1}\right)\end{array}$ & $<1.0$ & $<1.0$ & $<1.0$ & $<1.0$ & $<1.0$ & $<1.0$ & $<1.0$ & $<1.0$ & $<1.0$ & $<1.0$ & $<1.0$ \\
\hline & $\begin{array}{l}\text { Yeasts and Moulds } \\
\left(\text { CFU.mL } \mathrm{mL}^{-1}\right)\end{array}$ & $<10^{1}$ & $<10^{1}$ & $<10^{1}$ & $<10^{1}$ & $<10^{1}$ & $<10^{1}$ & $<10^{1}$ & $<10^{1}$ & $<10^{1}$ & $<10^{1}$ & $<10^{1}$ \\
\hline \multirow[t]{2}{*}{30 days } & $\begin{array}{l}\text { Total Count } \\
\left.\text { (CFU.mL }{ }^{-1}\right)\end{array}$ & $1.6 \cdot 10^{3}$ & $2.3 \cdot 10^{3}$ & $5.0 \cdot 10^{3}$ & $<1.0$ & $2.9 \cdot 10^{3}$ & $<1.0$ & $5.0 \cdot 10^{3}$ & $<1.0$ & $<1.0$ & $5.0 \cdot 10^{\circ}$ & $<1.0$ \\
\hline & $\begin{array}{l}\text { Yeasts and Moulds } \\
\left(\text { CFU.mL } L^{-1}\right)\end{array}$ & $2.8 \cdot 10^{4}$ & $1.0 \cdot 10^{3}$ & $5.0 \cdot 10^{3}$ & $<1.0$ & $1.9 \cdot 10^{5}$ & $<1.0$ & $1.4 \cdot 10^{5}$ & $<1.0$ & $5.0 \cdot 10^{2}$ & $<1.0$ & $<1.0$ \\
\hline \multirow[t]{2}{*}{61 days } & $\begin{array}{l}\text { Total Count } \\
\left.\text { (CFU.mL }{ }^{-1}\right)\end{array}$ & $5.0 \cdot 10^{1}$ & $5.0 \cdot 10^{1}$ & $<1.0$ & $<1.0$ & $5.8 \cdot 10^{4}$ & $<1.0$ & $5.9 \cdot 10^{4}$ & $<1.0$ & $<1.0$ & $<1.0$ & $<1.0$ \\
\hline & $\begin{array}{l}\text { Yeasts and Moulds } \\
\left.\text { (CFU.mL }{ }^{-1}\right)\end{array}$ & $9.2 \cdot 10^{5}$ & $<1.0$ & $<1.0$ & $<1.0$ & $1.4 \cdot 10^{6}$ & $1.0 \cdot 10^{\circ}$ & $1.1 .10^{6}$ & $<1.0$ & $<1.0$ & $5.0 \cdot 10^{1}$ & $<1.0$ \\
\hline
\end{tabular}


maintain the microbiological quality of the product through the storage period when the raw material had a high microbiological load. In these confirmatory trials, the initial counts were over $10^{2} \mathrm{CFU} \cdot \mathrm{mL}^{-1}$ for the total count and almost $10^{1} \mathrm{CFU} \cdot \mathrm{mL}^{-1}$ for the yeasts and moulds. This last result highlights the importance of good manufacturing practices in order to reduce or avoid contamination of the product.

\section{Conclusion}

The present results indicated that the samples presented less alterations when higher concentrations of the preservatives were added. However, such concentrations were above the limits established by Brazilian law. For the sample with concentrations of $260 \mathrm{mg} . \mathrm{L}^{-1}$ of potassium sorbate and $40 \mathrm{mg} \cdot \mathrm{L}^{-1}$ of sodium metabisulphite, which are the limits established by the legislation, good stability of the carbonated coconut water was observed for approximately 60 days of storage at room temperature, provided the initial microbial counts were low. It was also observed that the samples that received only one type of preservative presented less stability, demonstrating a possible synergistic effect between potassium sorbate and sodium metabisulphite. Moreover, this study showed that the addition of $\mathrm{CO}_{2}$ to the coconut water, besides giving a more refreshing sensation to the beverage, also contributed to its conservation because it helped to reduce the $\mathrm{pH}$ value of the product, as well as reducing the amount of dissolved oxygen.

\section{References}

AMERICAN SOCIETY FOR TESTING AND MATERIALS - ASTM. ASTM F1115-95: Standard Test Method for Determining the Carbon Dioxide Loss of Beverage Containers. West Conshohocken: ASTM, 2001. p. 1-12.

ABREU, L. F.; FARIA, J. A. F. Influência da Temperatura e do Ácido Ascórbico sobre a Estabilidade Físico-química e Atividade Enzimática de Água de Coco (Cocos nucifera L.) Acondicionada Assepticamente. Ciência e Tecnologia de Alimentos, Campinas, v. 2, p. 226-232, 2007. http://dx. doi. org/10.1590/S0101-20612007000200003

BRASIL. Agência Nacional de Vigilância Sanitária. Resolução RDC $n^{\circ} 5$, de 15 de janeiro de 2007. Aprova o regulamento técnico sobre uso de aditivos em bebidas não alcoólicas carbonatadas e não carbonatadas. Diário Oficial da República Federativa do Brasil, Brasília, DF, 21 ago. 2007. Disponível em: <https://anvisa.gov.br/legis/resol/2007/rdc/05_ 170107rdc.htm>. Acesso em: 13 dez. 2008.

BRASIL. Ministério da Agrigultura, Pecuária e Abastecimento. Instrução Normativa n $n^{\circ} 27$, de 22 de julho de 2009. Estabelece os procedimentos mínimos de controle higiênico-sanitário, padrões de identidade e características mínimas de qualidade gerais para a água de coco. Alterada pela Instrução Normativa n 31 de 13 de agosto de 2009. Diário Oficial da República Federativa do Brasil, Brasília, DF, 23 jul. 2009. Disponível em: <http://www.inmetro.gov.br/barreirastecnicas/pontofocal/..\%5C pontofocal\%5Ctextos\%5Cregulamentos\%5CBRA_320_ADD_1. htm>. Acesso em: 12 set. 2012.

CAMPOS, C. F.; SOUZA, P. E. A.; COELHO, J. F.; GLÓRIA, M. B. A. Chemical composition, enzyme activity and effect of enzyme inactivation of flavour quality of green coconut water. Journal of Food Processing and Preservation, Malden, v. 20, p. 487-500, 1996. http://dx.doi.org/10.1111/j.1745-4549.1996. tb00761.x

CARVALHO, J. M.; MAIA, G. A.; FIGUEIREDO, R. W.; BRITO, E. S.; RODRIGUES, S. Storage Stability of Stimulant Coconut WaterCashew Apple Juice Beverage. Journal of Food Processing and Preservation, Malden, v. 31, p. 178-189, 2007a. http:// dx.doi.org/10.1111/j.1745-4549.2007.00121.x

CARVALHO, J. M.; MAIA, G. A.; FIGUEIREDO, R. W.; BRITO, E. S.; RODRIGUES, S. Development of a Blended Nonalcoholic Beverage Composed of Coconut Water and Cashew Apple Juice Containing Caffeine. Journal of Food Quality, Malden, v. 30, p. 664-681, 2007b. http://dx.doi.org/10.1111/j.17454557.2007.00149.x

CHOWDHURY, M. M.; AZIZ, M. G.; UDDIN, M. B. Development of Shelf-stable Ready-to-serve Green Coconut Water. Biotechnology, Weinheim, v. 2, p. 121-125, 2005.

DUARTE, A. C. P.; COELHO, M. A. S.; LEITE, S. G. F. Identification of Peroxidase and Tyrosinase in Green Coconut Water. Ciencia y Tecnología Alimentaria, Reynosa, v. 5, p. 266-270, 2002.

FARIA, J. A. F. Department of Food Technology Faculty of Food Engineering at Unicamp. Carbonatador de bebidas. Campinas: Unicamp, 2007.

FREITAS, A. A.; FRANCELIN, M. F.; HIRATA, G. F.; CLEMENTE, E.; SCHIMIDT, F. L. Atividades das Enzimas Peroxidase (POD) e Polifenoloxidase (PPO) nas Uvas das Cultivares Benitaka e Rubi e em seus Sucos e Geléias. Ciência e Tecnologia de Alimentos, Campinas, v. 1, p. 172-177, 2008. http://dx.doi. org/10.1590/S0101-20612008000100025

FOOD AND AGRICULTURE ORGANIZATION OF THE UNITED NATIONS - FAO. Toxicological evaluation of some antimicrobials, antioxidants,emulsifiers, stabilizers, flourtreatment agents, acids and bases. FAO, 1967. Disponível em: <http://www.inchem.org/pages/jecfa.html>. Acesso em: 13 set. 2012.

GUERRERO-BELTRÁN, J. A.; SWANSON, B. G.; BARBOSACÁNOVAS, G. V. Inhibition of Polyphenoloxidase in Mango Puree with 4-Hexylresorcinol, Cysteine and Ascorbic Acid. LWT - Food Science and Technology, Amsterdam, v. 6, p. 625-630, 2005.

HORWITZ, W. (Ed.). Official Methods of Analysis of the Association of Official Analytical Chemists. 16th ed. Gaithersburg: AOAC, 1997. 
Optimizing the use of potassium sorbate and sodium metabisulphite for the chemical and microbial stability of carbonated coconut water

PEREIRA, E. P. R. et al.

LIMA, A. S.; MAIA, G. A.; SOUSA, P. H. M.; PRADO, G. M.; RODRIGUES, S. Storage Stability of a Stimulant Coconut WaterAcerola Fruit Juice Beverage. International Journal of Food Science and Technology, Oxford, v. 44, p. 1445-1451, 2009. http://dx.doi.org/10.1111/j.1365-2621.2009.01977.x

MACIEL, M. I.; OLIVEIRA, S. L.; SILVA, I. P. Effects of Different Storage Conditions on Preservation of Coconut (Cocus nucifera) water. Journal of Food Process and Preservation, Malden, v. 16, p. 13-22, 1992. http://dx.doi.org/10.1111/j.1745-4549.1992. tb00189.x

MAGA, J. A.; TU, A. T. Food Additive Toxicology. New York: Marcel Dekker INC, 1994. 542 p.

MEDINA, J. C.; GARCIA, J. L. M.; MARTIN, Z. J.; KATO, K.; TERUO, P.; TURATTI, J. M.; SANTOS, L. C.; SILVA, M. T. C.; CANTO, W. L.; BICUDO NETO, L. C.; MORETTI, V. A. Coco: da Cultura ao Processamento e Comercialização. Campinas: Série Frutas Tropicais, ITAL, 1980. 285 p.

MITCHELL, A. J. Formulation and Production of Carbonated Soft Drinks. New York: Blackie And Son Ltd, 1990. 361 p.

MURASAKI-ALIBERTI, N. C.; SILVA, R. M. S.; GUT, J. A. W.; TADINI, C. C. Thermal Inactivation of Polyphenoloxidase and Peroxidase in Green Coconut (Cocos nucifera) Water.
International Journal of Food Science and Technology, Malden, v. 44, p. 2662-2668, 2004.

QUEIROZ, C.; MENDES, M. L. L.; FIALHO, E.; VALENTEMESQUITA, V. L. Polyphenol Oxidase: Characteristics and Mechanisms of Browning Control. Food Reviews International, Philadelphia, v. 4, p. 361-375, 2008. http://dx. doi. org/10.1080/87559120802089332

SILVA, N.; JUNQUEIRA, V. C. A.; SILVEIRA, N. F. A.; TANIWAKI, M. H.; SANTOS, R. F. S.; GOMES, R. A. R. Manual de Métodos de Análise Microbiológica de Alimentos. 4. ed. Campinas: Livraria Varela, 2010. p. 107-122.

SILVA, C. R. R.; MAIA, G. A.; RODRIGUES, M. C. P.; COSTA, J. M. C.; FIGUEIREDO, R. W.; SOUSA, P. H. M.; FERNANDES, A. G. Estabilidade da Água de Coco Submetida ao Processo "Hot-Pack". Publicatio UEPG: Ciências Exatas e da Terra, Ciências Agrárias e Engenharias, Ponta Grossa, v. 3, p. 15-21, 2003.

TORALLES, R. P.; VENDRUSCOLO, J. L.; VENDRUSCOLO, C. T.; DEL PINO, F. A. B.; ANTUNES, P. L. Determinação das Constantes Cinéticas de Degradação do Ácido Ascórbico em Purê de Pêssego: Efeito da Temperatura e Concentração. Ciência e Tecnologia de Alimentos, Campinas, v. 1, p. 18-23, 2008. http:// dx.doi.org/10.1590/S0101-20612008000100004 